\title{
Mosquitoes (Diptera: Culicidae) in Tunisia, with Particular Attention to Proven and Potential Vectors: A Review
}

\author{
Ahmed Tabbabi ${ }^{1 *}$, Adel Rhim ${ }^{2}$ and Jabeur Daaboub ${ }^{1}$ \\ ${ }^{1}$ Department of Hygiene and Environmental Protection, Ministry of Public Health, Tunisia \\ ${ }^{2}$ Laboratory of Medical Entomology, Pasteur Institute of Tunis, Tunisia
}

*Corresponding author: Tabbabi A, Department of Hygiene and Environmental Protection, Ministry of Public Health, Tunisia, Tel: +0021697085424; E-mail: tabbabiahmed@gmail.com

Received date: September 10, 2017; Accepted date: October 17, 2017; Published date: October 25, 2017

Copyright: (C) 2017 Tabbabi A, et al. This is an open-access article distributed under the terms of the Creative Commons Attribution License, which permits unrestricted use, distribution, and reproduction in any medium, provided the original author and source are credited.

\begin{abstract}
The state of knowledge of mosquitoes (Diptera: Culicidae) is dispersed and disorganized in Tunisia although their important role as disease vectors. The available published and unpublished reports were collected and reviewed. There are about 43 species of mosquitoes in Tunisia. There are a total of 12 species of Anopheles. The species involved in malaria transmission in Tunisia during the endemic period and still persisting in Tunisia are Anopheles (An.) labranchiae, predominant species in the north and center of the country, An. sergenti and An. multicolor in the Center and South. The genus Culex contains 11 species. Culex (Cx.) pipiens is the most dangerous specie and their distribution is ubiquitous in Tunisia. This mosquito has been implicated in the transmission of West Nile virus (WNV) in Tunisia. Concerning vectors, Aedes aegypti was reported in Tunisia before 2000, but was not encountered later. Moreover, Aedes albopictus, the other vector of Dengue and Chikungunya, is not among the 43 species of mosquitoes described in Tunisia, but the latter circulates in neighboring countries. Collected and analyzed data will help current and future research on mosquitoes particularly in the field of medical entomology to develop and implement vector control strategies.
\end{abstract}

Keywords: Culicidae; Mosquitoes; Vectors; West Nile virus; Malaria; Arbovirus; Tunisia

\section{Introduction}

There are about 3500 species of mosquitoes. The first three stages of life (egg, larva, and nymph) are aquatic and the adult stage (imago), which lives from one to twelve weeks, evolves in the air environment. Mosquitoes are sometimes just nuisance, but especially in intertropical zones, they are vectors of parasitoses and/or arboviruses. Their impact on human health is considerable.

Three genera are the main vectors: Anopheles, Aedes and Culex. Anopheles transmits malaria, filaria and arbovirus. Aedes and Culex are mainly vectors of arboviruses. Vaccines or treatments of these vector-borne diseases are sometimes available and effective. However, the best prevention against all these diseases is to avoid the bite by the knowledge of the periods of activity of each mosquito and by the use of repellents or insecticides.

Mosquitoes are insects that belong to the family Culicidae, classified in the order of Diptera and suborder of Nematoceras. There are about 3500 species worldwide and 44 genera [1]. The genera Anopheles contains seven subgenera including 460 species, Culex comprises 26 subgenera with 763 species and the genus Aedes including 70 subgenera with 927 species [1,2].

In 1994, WHO divided the world into 4 major zones, according to their situation with regard to malaria [3]. Tunisia belongs to the group of countries that have successfully completed their campaigns to eliminate malaria and who have been able to maintain the benefit of this success. Indeed, it was in 1979 that the last case of indigenous transmission was reported [4]. Since then, and for the last thirty years, the only registered malaria cases have been imported. However, the emergence of import malaria, the persistence of a local anopheline and the potential risk of importing or implanting a new efficient vector are elements that can facilitate the recovery of endemic malaria [5]. This risk is related to the degree of exposure to the importation of cases, i.e., to "vulnerability", as well as to the prevalence of vectors and their behavior, ie to "receptivity". The latter, defined as the risk of resumption of local transmission of infection, depends on the presence and density of local malaria vectors as well as climatic, ecological, genetic and other factors favoring their infectivity [6].

Moreover, the spatial distribution of Anopheles species is changing due to increasing urbanization and, above all, ecological changes in the urban settlements, leading to a significant depletion of the breeding sites and consequently of the density of the Anopheles to the benefit of the outbreak of that of $C x$. pipiens, more adapted to this type of lodgings. Indeed, as an example, anophelines accounted for only 1-3\% of mosquito larvae caught in the Tunis region [7].

The epidemiological situation of the WNV in Tunisia has shown a high risk in many areas, depending on environmental factors: wetlands and climate favorable to wild bird populations and Culex mosquitoes. The high rate of seroprevalence observed is compatible with the hypothesis of an endemic circulation of WNV without excluding the possibility of repeated introductions. Monthly serological monitoring detected the circulation of the virus at the end of the warm season (September, October) near wetlands during periods of high mosquito activity and abundance of wild birds.

The state of knowledge of mosquitoes is dispersed and disorganized in Tunisia although their important role as disease vectors. The available published and unpublished reports on biodiversity, distribution and ecology of mosquito species were collected, reviewed 
and discussed in relation to possible extension in Tunisia of mosquitoborne arboviruses already present on our soil or likely to be imported. This paper provides the first comprehensive review on mosquitoes in Tunisia.

\section{Country Profile}

\section{2-1-geography}

Tunisia is located between Algeria to the west and Libya to the south-east (Figure 1). It has two waterfronts on the Mediterranean, to the north and east, and extends to the desert Saharan regions to the south. It covers $163,620 \mathrm{~km}^{2}$, between $8^{\circ}$ and $18^{\circ}$ east longitude, and $28^{\circ}$ and $32^{\circ}$ north latitude. Tunisia has a contrasted relief with a northern and western mountainous part in the extension of the Atlas Mountains. To the east lies the plain of the Sahel region. The southern part of the country, mainly desert, is divided between a succession of saline waters called Chotts, rocky plateaus and dunes of the Great Oriental Erg.

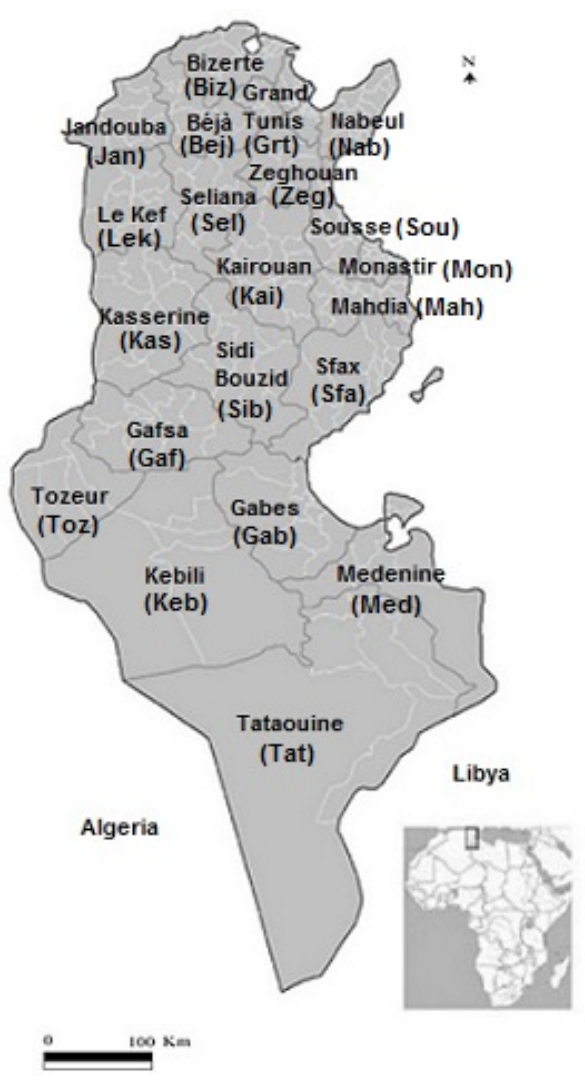

Figure 1: Map of Tunisia with its administrative regions. Administrative district codes are provided in parentheses.

\section{Climate, temperatures, precipitation, sunshine and vegetation}

Tunisia's climate is divided into seven bioclimatic zones that range from a humid Mediterranean climate in the northwest, then arid or semi-arid, and increasingly desert towards the Sahara. Temperatures vary according to latitude, altitude and proximity to the Mediterranean Sea. Annual rainfall increases from more than one meter in the northwestern part of the country to about $380 \mathrm{~mm}$ in the center and between 20 and $50 \mathrm{~mm}$ in the south. The Medjerda, in the north of the country, is the only continuously fed stream. The central part of the country consists of steppes, and the desert covers one third of the territory to the south [8].

\section{Classification of wetlands in Tunisia}

Tunisian wetlands are very diverse, including Garaas or lakes: these are freshwater areas within the country. They may be temporary (as gaaret el Mabtouh) or permanent (as gaaret Ichkeul). They are generally located in the north of the country where rainfall is high. (Lake Ichkeul receives 150,000 migratory birds annually); Freshwater or brackish marshes: they are associated with frequent flooding or the accumulation of water bodies and run-off; Peat bogs: accumulations of dead plants in a highly acidic and oxygen deficient flooded environment with very slow decomposition. The lagoons: these are saline wetlands, located from north to south of the country, of varying depths and connected to the sea by one or more channels. Their area varies from a few hectares to several thousand hectares. There are mainly avocets, white stilts and terns; the intertidal marshes: these are spaces at the edge of the sea that are discovered in low marsh. They are often bordered by a sandy beach, their surface depends on the marsh, and they are part covered by vegetation composed of eelgrass which offers a place of food important for the birds in particular the waders. They extend from Sfax to Djerba; the sebkhas: these are depressions that retain water, usually brackish or salted over an area ranging from a few hundred to a few thousand hectares. They are located from north to south. (Example: sebkha of Sijoumi, sebkha of Kelibia); Chotts: these are large, shallow depressions, covering thousands of irregularly flooded hectares. During the dry season, a crust of salt forms on the surface. They are located at the northern limit of the Sahara, (example: Chott El Jérid).

\section{Administrative divisions}

The country is sub-divided into 24 governorates of which Grand Tunis area comprises 4 governorates (Figure 1). The governorates are subdivided into 264 delegations and 2,073 sectors.

\section{Population}

Improved living standards resulted in a demographic transition in the 1990s. The fertility rate decreased between the 1960s and 2008, from almost 6 to 1.8 children per woman. In 2011, the total population was estimated at just fewer than 10.7 million. It is urbanized at more than $67 \%$ and relatively young, fewer than 15 and over 60 years respectively accounting for $24 \%$ and $10 \%$ of the population. The main urban centers on the eastern coastal strip are the capital of Tunis and the cities of Sfax and Sousse [9].

\section{Culicidae Fauna in Tunisia}

There are about 43 species of mosquitoes in Tunisia (Table 1). 
Citation: Tabbabi A, Rhim A, Daaboub J (2017) Mosquitoes (Diptera: Culicidae) in Tunisia, with Particular Attention to Proven and Potential Vectors: A Review. J Trop Dis 5: 249. doi:10.4172/2329-891X.1000249

Page 3 of 8

\begin{tabular}{|c|c|c|c|c|}
\hline \multirow[t]{2}{*}{ Genus } & \multicolumn{2}{|c|}{ Species } & \multirow[t]{2}{*}{ Distribution $^{\mathrm{b}}$} & \multirow[t]{2}{*}{ References } \\
\hline & Before $2000^{a}$ & Recent $^{\mathrm{a}}$ (2000-present) & & \\
\hline \multirow[t]{12}{*}{ Anophles spp } & An. algeriensis & An. algeriensis & Jan, Grt, Nab, Sou, Toz, Gab Keb & $\begin{array}{l}\text { (Boucheté et al., 1991; Bouattour et al., } \\
\text { 1993; Brunhes et al., 1999; 2000; Tabbabi } \\
\text { et al., 2015) }\end{array}$ \\
\hline & $\begin{array}{l}\text { An. cinerus (syn. An. } \\
\text { hispaniola) }\end{array}$ & - & Jan, Kas, Toz, Keb, Med, Tat & $\begin{array}{l}\text { (Boucheté et al., 1991; Brunhes et al., } \\
\text { 1999; 2000) }\end{array}$ \\
\hline & An. claviger & - & Jan & $\begin{array}{l}\text { (Bouattour et al., 1993; Brunhes et al., } \\
\text { 1999; 2000) }\end{array}$ \\
\hline & An. dthali & - & Jan, Toz & (Brunhes et al., 1999; 2000) \\
\hline & An. labranchiae & An. labranchiae & $\begin{array}{l}\text { Grt, Biz, Jan, Bej, Sou, Mon, Kas, } \\
\text { Kai, Sfa, Gab, Toz, Keb }\end{array}$ & $\begin{array}{l}\text { (Boucheté et al., 1991; Bouattour et al., } \\
\text { 1993; Krida et al., 1998; Brunhes et al., } \\
\text { 1999; 2000; Tabbabi et al., 2015) }\end{array}$ \\
\hline & An. marteri & - & Jan & (Brunhes et al., 1999; 2000) \\
\hline & An. multicolor & An. multicolor & $\begin{array}{l}\text { Grt, Sou, Sfa, Sib, Toz, Gab, Keb, } \\
\text { Med, Tat }\end{array}$ & $\begin{array}{l}\text { (Boucheté et al., 1991; Krida et al., 1998; } \\
\text { Brunhes et al., 1999; 2000; Tabbabi et al., } \\
\text { 2015) }\end{array}$ \\
\hline & An. petragnani & - & Sfa & (Brunhes et al., 1999; 2000) \\
\hline & An. plumbeus & - & Biz, Toz & (Brunhes et al., 1999; 2000) \\
\hline & An. sergenti & An. sergenti & Zag, Kai, Sib, Toz, Tat & $\begin{array}{l}\text { (Boucheté et al., 1991; Krida et al., 1998; } \\
\text { Brunhes et al., 1999; 2000; Tabbabi et al., } \\
\text { 2015) }\end{array}$ \\
\hline & An. superpictus & - & Jan & (Brunhes et al., 1999; 2000) \\
\hline & $\begin{array}{l}\text { An. ziemanni (Syn. An. } \\
\text { coustani) }\end{array}$ & - & Jan, Bej, Zag, Kai, Gaf & (Brunhes et al., 1999; 2000) \\
\hline \multirow[t]{11}{*}{ Culex spp } & Cx. antennatus & - & $?$ & (Brunhes et al., 1999; 2000) \\
\hline & Cx. deserticola & - & Biz, Jan, Toz, Gab, Gaf & (Brunhes et al., 1999; 2000) \\
\hline & Cx. hortensis & - & Nab, Grt, Biz, Jan, Toz, Med & (Brunhes et al., 1999; 2000) \\
\hline & Cx. impudicus & - & Nab, Grt, Lek, Zag, Sel & (Brunhes et al., 1999; 2000) \\
\hline & Cx. laticinctus & - & Nab, Toz, Keb, Med, Tat & $\begin{array}{l}\text { (Bouattour et al., 1998; Brunhes et al., } \\
\text { 1999; 2000) }\end{array}$ \\
\hline & Cx. mimeticus & - & Jan, Biz & (Brunhes et al., 1999; 2000) \\
\hline & Cx. perexiguus & - & Lek, Biz, Grt, Sou, Toz, Keb, Tat & $\begin{array}{l}\text { (Bouattour et al., 1998; Brunhes et al., } \\
\text { 1999; 2000) }\end{array}$ \\
\hline & Cx. pipiens & Cx. pipiens & $\begin{array}{l}\text { Biz, Grt, Nab, Zag, Sel, Bej, Elk, } \\
\text { Jan, Sou, Mon, Mah, Kai, Kas, } \\
\text { Gaf, Toz, Sfa, Gab, Med, Keb, Tat }\end{array}$ & $\begin{array}{l}\text { (Bouattour et al., 1998; Brunhes et al., } \\
\text { 1999; 2000; Krida et al., 2011; 2015; } \\
\text { Tabbabi et al., 2016; 2017) }\end{array}$ \\
\hline & Cx. pusillus & - & Toz, Keb, Med & (Brunhes et al., 1999; 2000) \\
\hline & Cx. territans & - & $?$ & (Brunhes et al., 1999; 2000) \\
\hline & Cx. Theileri & - & $\begin{array}{l}\text { Biz, Jan, Grt, Nab, Elk, Mon, Sou, } \\
\text { Gab, Keb, Tat }\end{array}$ & $\begin{array}{l}\text { (Bouattour et al., 1998; Brunhes et al., } \\
\text { 1999; 2000) }\end{array}$ \\
\hline \multirow[t]{3}{*}{ Aedes spp } & Ae. albineus & - & Toz & (Brunhes et al., 1999; 2000) \\
\hline & Ae. berlandi & - & Jan, Biz & (Brunhes et al., 1999; 2000) \\
\hline & Ae. caspius & - & $\begin{array}{l}\text { Biz, Grt, Nab, Sou, Med, Gab, } \\
\text { Keb, Toz }\end{array}$ & (Brunhes et al., 1999; 2000) \\
\hline
\end{tabular}




\begin{tabular}{|c|c|c|c|c|}
\hline & Ae. detritus & - & Biz, Tun, Nab, Kai, Kas, Toz, Med & (Brunhes et al., 1999; 2000) \\
\hline & Ae. dorsalis & - & Nab, Grt, Toz & (Brunhes et al., 1999; 2000) \\
\hline & Ae. mariae & - & $\mathrm{Nab}, \mathrm{Biz}$ & (Brunhes et al., 1999; 2000) \\
\hline & Ae. zammitii & - & $\mathrm{Nab}$ & (Brunhes et al., 1999; 2000) \\
\hline & Ae. pulcritarsis & - & Biz, Grt & (Brunhes et al., 1999; 2000) \\
\hline & Ae. echinus & - & Jan & (Brunhes et al., 1999; 2000) \\
\hline & Ae. geniculatus & - & Jan, Toz, Med & (Brunhes et al., 1999; 2000) \\
\hline & Ae. vexans & - & Gab, Tat & (Brunhes et al., 1999; 2000) \\
\hline & Ae. Vittatus & - & $\mathrm{Nab}$ & (Brunhes et al., 1999; 2000) \\
\hline & Ae aegypti & - & Biz, Toz, Gab, Med & (Brunhes et al., 1999; 2000) \\
\hline & Ae. coluzzi & - & Gab & $\begin{array}{l}\text { (Rioux et al., } 1998 \text {; Brunhes et al., 1999; } \\
2000 \text { ) }\end{array}$ \\
\hline \multirow[t]{5}{*}{ Culiseta spp } & Cs.annulata & - & Jan, Toz & (Brunhes et al., 1999; 2000) \\
\hline & Cs. fumipennis & - & Jan & (Brunhes et al., 1999; 2000) \\
\hline & Cs. longiareolata & - & $\begin{array}{l}\text { Biz, Grt, Zag, Nab, Sou, Kai, Toz, } \\
\text { Gab, Tat, Med }\end{array}$ & (Brunhes et al., 1999; 2000) \\
\hline & Cs. morsitans & - & ? & (Brunhes et al., 1999; 2000) \\
\hline & Cs. subochrea & - & Grt, Nab, Med & (Brunhes et al., 1999; 2000) \\
\hline Uranotaenia spp & U. unguiculata & - & Zag, Toz, Med, Tat & (Brunhes et al., 1999; 2000) \\
\hline \multicolumn{5}{|c|}{$\begin{array}{l}\text { Abbreviations: Biz Bizerte, Grt Grand Tunis, Nab Nabeul, Zag Zaghouan, Elk El Kef, Bej Beja, Jan Jandouba, Sel Seliana, Kai Kairouan, Sou Sousse, Mon Monastir } \\
\text { Mah Mahdia, Kas Kasserine, Sib Sidi Bouzid, Sfa Sfax, Gaf Gafsa, Toz Tozeur, Gab Gabes, Keb Kebili Med Medenine, Tat Tataouine, ? Cited without location. }\end{array}$} \\
\hline
\end{tabular}

Table 1: List of the Culicidae species and their distribution in Tunisia.

\section{Anopheles spp}

The mosquitoes of the genus Anopheles, of which some species are vectors of malaria, continue to be rampant in Tunisia as in all the Maghreb. The first map of the distribution of Anopheles was established, rather artificially, from data collected between 1968 and 1974 , i.e., during the malaria eradication campaign. The last distribution map and the ecology of the Anopheles of Tunisia (1989-1994) were established by the Laboratory of Medical Entomology of the Pasteur Institute of Tunis [10].

There are a total of 12 species of Anopheles, none of which are specific to Tunisia (Table 1): Anopheles (An.) algeriensis, An. cinerus (syn. An. hispaniola), An. claviger, An. dthali, An. labranchiae (maculipennis complex), An. marteri, An. multicolor, An. petragnani, An. plumbeus, An. sergenti, An. superpictus, and An. ziemanni (Syn. An. coustani).

The northern part of Tunisia, where the weather conditions differ little from southern Europe, contains species that can be considered as northern: An. labranchiae, An. claviger, An. plumbeus and An. marteri. The last three species are confined to the humid bioclimatic stage (North West of Tunisia and in the Kroumirie mountains where winter is well marked and humid). Studies [10], based on adult catches in the north of the country have shown that An. labranchiae is the most abundant species (An. Labranchiae (98\%), An. Algeriensis $(1.8 \%)$, An. claviger $(0.25 \%))$. On the other hand, in the center and in the south of Tunisia the breeding sites of the arid and Saharan zones are populated by An. sergenti (38\%), An. multicolor (32\%), An. cinereus (24.7\%), An. algeriensis (4.5\%), and An. labranchiae (0.8\%) [11].

According to morphological identification, four species were recorded [12]: An. labranchiae $(\mathrm{N}=252 ; 38.9 \%)$, An. multicolor $(\mathrm{N}=233 ; 36 \%)$, An. sergentii $(\mathrm{N}=150 ; 23.2 \%)$, and An. algeriensis $(\mathrm{N}=12 ; 1.9 \%)$. The species involved in malaria transmission in Tunisia during the endemic period and still persisting in Tunisia are $A n$. labranchiae, predominant species in the north and center of the country, An. sergenti and An. multicolor in the Center and South.

Anopheles labranchiae is the major vector of malaria in the north of the country. This species is more abundant and more frequent north of the ridge (isohyet 400-800), particularly in humid, sub-humid and semi-arid bioclimaticn zones. Before the national malaria eradication program, this species could be found in several sites of the arid and even of the Sahara but sporadically. Recent studies have shown that the deposits of this anopheline in these areas have become very exceptional. In Tunisia, the lodgings of An. labranchiae have been extensively described by different authors. The typical deposit is 
represented by a wadi of sunny plain, slow running or low water (hopscotch) encumbered with vegetation both horizontal and vertical. Fresh or brackish water is usually encumbered with floating or submerged plants (Potamogetons, Characeae) which constitute a thick felting where the larvae find both shelter and food. This species is found in dense sites in a humid zone with clear water with a sunny temperature of $15^{\circ}$ to $35^{\circ}$, salinity ranging from $0.15 \mathrm{~g} / \mathrm{l}$ to $6 \mathrm{~g} / \mathrm{l}$ and a $\mathrm{pH}$ between 2.6 and 8,9 [12]. The depth of the water varies according to the type of deposit, from $5 \mathrm{~cm}$ to $2 \mathrm{~m}$ (edge of wadis, ponds, hilly lakes ..). The activity of this mosquito extends from June to October, with a peak between July and August.

Anophles sergenti has been designated by Iyengar and Wernsdorfer [13], as the main vector of malaria in southern Tunisia. It is a species of the Southern Mediterranean which the ancients designated as a "rocky and mountainous species". We find it in southern Tunisia (arid and Saharan bioclimatic zones), preferentially in oases, mountains and chotts. Anthropozoophagous species, the biotopes of this anopheles are located, particularly in the oases where it colonizes the séguias where the water is current, clear, with the presence of algae. It appears to be demanding for oxygen in the aquatic environment and is often associated with Similidae larvae.

\section{Culex spp}

The genus Culex contains 11 species (Table 1): Culex. antennatus, $C x$. deserticola, $C x$. hortensis, $C x$. impudicus, $C x$. laticinctus, $C x$. mimeticus, $C_{x}$. perexiguus, $C x$. pipiens, $C x$. pusillus, $C_{X}$. territans, $C_{X}$. Theileri. It should be noted that $C_{X}$. pipiens is the most dangerous specie and its distributions is ubiquitous in Tunisia. In urban areas, authors found $C x$. pipiens pipiens [14], populations which are autogenous, stenogamous, anthropophilic $[15,16]$ and sometimes anautogenous $[17,18]$. In rural areas, $C X$. pipiens molestus were mentionned in Tunisia [14], which are anautogenous, stenogamous, anthropophilic or ornithophilic [19]. In Tunisia, mosquitoes (Culicidae) are a real source of nuisance by their bites, especially in urban areas where there is a multiplication of industrial units and population growth. In the absence of an adequate sewage disposal network of many favorable deposits, the larval development of mosquitoes and particularly $C x$. pipiens, take extension. This leads to increased proliferation of these insects, sometimes reaching levels deemed intolerable [20].

Vector capacity has been studied in several mosquito species. Mosquitoes belonging to the genus Culex are considered to be the major vectors of WNV. Culex pipiens is the potential vector of the disease in Tunisia. An entomological survey was carried out in Tunisia after the epidemic of 1997 [21]. The Culex genus in Tunisia has the following results: Culex pipiens it is a species that supports brackish waters (salinity of the deposits varies from $0.24 \mathrm{~g} / \mathrm{l}$ to $2.75 \mathrm{~g} / \mathrm{l}$ ). Her breathing allows her to survive in very low oxygen environments. It is therefore endowed with an ecological plasticity allowing it to colonize different types of shelters, it is very widespread in Tunisia. The greatest densities are found in stagnant waters rich in organic matter; Culex theileri: it occupies very different lodgings which explain its distribution throughout the Tunisian territory. It supports brackish water $(0.5 \mathrm{~g} / \mathrm{l}$ to $11 \mathrm{~g} / \mathrm{l})$; Culex laticinctus. it is very widespread in Tunisia, adapts to various types of deposits even with brackish water. Adults of this species are frequently observed from August to October. It is an exophagous zoophilic species; Culex perexiguus: it occupies freshwater and salt ponds with or without vegetation. Adults are active from September to November. It is an entropozoophilic species.

\section{Aedes spp}

The genus Aedes contains 14 species (Table 1): Ae. albineus, Ae. berlandi, Ae caspius, Ae. detritus, Ae dorsalis, Ae mariae, Ae. zammitii, Ae pulcritarsis, Ae echinus, Ae geniculatus, Ae. vexans, Ae. vittatus, Ae. coluzzi, and Ae aegypti. It should be noted that Ae aegypti is the most dangerous specie and its distributions was/is ubiquitous in Tunisia (Table 1). Aedes caspius and Ae. detritus are mainly anthropophilic species.

The results on the ecology of the genus Aedes in Tunisia are: Aedes detritus considered as potential vector of WNV: It is a halophilous species occupying the salt marshes along the Tunisian coast. It is a frequent and abundant species which pricks man during the day; Aedes Caspius considered as potential vector of WNV: It has the same ecology as the previous species and occupies the same biotope, in addition it can be encountered in continental regions (Sidi Bouzid, Tozeur); Aedes vittatus. it is collected only in the region of Meknassi; Ae. Geniculatus and Ae. Berlandi: these are strict tree species, they are found in the region of Ain Draham.

\section{Culiseta spp}

The genus Culiseta contains 5 species: Cs. annulata, Cs. fumipennis, Cs. longiareolata, Cs. morsitans and Cs. subochrea.

\section{Uranotaenia spp}

Uranotaenia contains just one species (Table 1): U. unguiculata.

\section{Discussion}

Studies on the vectorial capacity of Anopheles in the North (Nefza region) and in the Center (Sidi Bouzid region) of Tunisia have provided insight into the receptive potential of each region [10]. These studies were based on the calculation of the rate of aggressiveness of the Anopheles (number of bites per man per night) of the vectorial capacity index, in particular the trophic preference and the parturity rate. This work concluded that some sites remain receptive to malaria, particularly which caused by Plasmodium (P.) vivax, and therefore deserve special monitoring although the vector efficiency of these anophelines for the tropical Plasmodium strains is not yet known. However, recent work has been carried out to study the efficacy of Anopheles with respect to Plasmodium strains. This work made it possible to demonstrate experimentally that some species of Anopheles are receptive to Plasmodium strains [22]. In addition, the work of James and Ramsdale [23], demonstrated that An. Labranchiae, the species most at risk, would not be genetically receptive to Afro-tropical strains of $P$. falciparum but being close to An. maculipennis and An. atroparvus, vectors of $P$. vivax in Turkey, it would be able to transmit this species.

The vectorial capacity of the different species and the associated potential risks must take account of certain variables: the creation of hill lakes and the construction of new dams may lead to an increase in the number of breeding sites and consequently to the receptivity of certain areas to be maintained under strict supervision; Climate change observed since the early 1970s can promote the return of malaria and other diseases beyond the Sahara in the northern countries [24]. Global warming would have direct and often favorable consequences on the distribution and density of Anopheles on the one hand and especially on the ability of plasmodiums and arboviruses to develop in these mosquitoes. In fact, it is now accepted that even a few degrees of global warming cannot be a sufficient factor to allow 
malaria to return to the temperate countries that have eradicated it, or even exacerbate transmission in current endemic areas [25]. The importation of new, more competent species of mosquitoes, particularly in the context of intensified trade between our country and endemic, sub-Saharan and Asian countries. We can cite this rather explicit example of An. gambiae, a sub-Saharan African species that is highly competent for the transmission of $P$. falciparum and which has been described for the first time in southern Algeria [26].

The study of the behavior of Anopheles with respect to humans and their vectorial capacity make it possible to evaluate the risk of reintroduction of malaria in Tunisia. These results can be used to compare future situations as a result of ecological changes that could occur in these regions, since it is clear that since these studies, the environment, both plant and human, has evolved considerably. The reality of global warming and the quasi-periodic phenomenon ENSO (El Niño/Southern Oscillation) is now recognized by the scientific community. However, the real impact of climate change on the evolution of infectious diseases is more difficult to assess, although convincing examples can be drawn from the recent history of cholera, malaria, dengue or other diseases with vectorial transmission. Indeed, factors other than climatic, in particular anthropogenic, intervene in this evolution: continual increase of the world population, anarchic urbanization, politico-military conflicts, stoppage of the prevention campaigns, etc. But another disturbing aspect of the problem is the possible extension in Tunisia of arboviruses transmitted by mosquitoes already present on our soil (WNV) or likely to be imported (Chikungunya, dengue), their mosquito vectors probably already existing on the Tunisian territory.

The mosquito $C x$. pipiens has been implicated in the transmission of WNV in Tunisia. The bio-ecological characteristics of the species as well as certain environmental factors have favored the emergence of this virus in a previously free area. Many outbreaks of human WNV infections were identified in Tunisia in 1997, 2003 and 2012 [27-30]. Last authors reported sporadic cases in 2007, 2010, and 2011. Other authors showed an intensive circulation of WNV among humans, equines and birds. Jendouba, Nabeul, Sousse, Monastir, Sfax, Mednine and Djerba are considered as high-risk areas [31-34]. This scenario raises fears for the emergence of other arboviruses, including the Rift Valley Fever virus (RVF), which mainly affects small ruminants. The proximity of countries where the RVF virus circulates with which Tunisia maintains the trade in animals is not without risk. Recent studies [35], showed a low vectorial competence with RVF virus and a strong differentiation between populations showing a low dispersal capacity of the species. Thus, they concluded that even if the RVF virus was introduced, viral amplification in $C X$. pipiens, while possible, would not be associated with a spread of the virus through the mosquito. However, the emerging nature of the RVF virus and the presence of other potentially vector species (eg: Ochlerotatus caspius) must require the maintenance and even strengthening of zoo sanitary and entomological surveillance in order to limit the risk of introduction and circulation of the FVR virus in Tunisia [35].

The Dengue and Chikungunya viruses are arboviruses, the main vectors of which are the Ae. albopictus and Ae. aegypti mosquitoes. The chikungunya virus has been known since the 1950s and has already caused epidemics in Asia, Africa and the Indian Ocean. The years 2005 and 2006 were marked by a particularly intense circulation of this virus, not only in Réunion and Mayotte but also in other islands of the Indian Ocean, Comoros, Madagascar, Mauritius and Seychelles. In India, more than 1.4 million cases were counted in 2006. Pakistan,
Sri Lanka, Malaysia and the Maldives were also affected. In 2007, a major epidemic affected Gabon, causing more than 20,000 cases. The known circulation zone of the virus only concerned countries with a tropical climate until July 2007 when a chikungunya epidemic occurred in Italy, in the province of Ravenna, region Emilia Romagna: 249 cases were reported for their vast majority in 2 neighbouring communes. The suspected index case was a person returning from India (Kerala). Since the beginning of 2008, an upsurge in chikungunya cases has been described in Southeast Asia, notably in Indonesia, Malaysia, India and Sri Lanka [36,37]. Dengue fever is endemic-epidemic in the Caribbean and the Latin American continent, in Oceania, in the South Pacific and Indian Ocean islands, in South and Southeast Asia, and in the countries of inter-tropical Africa. More than 70\% of the burden of disease is recorded in SouthEast Asia and the Western Pacific. This virus circulates regularly in the French departments of the Americas (Martinique, Guadeloupe, Guyana) in the French islands of the Pacific and the Indian Ocean.

In France, since 2006 from May to November, an active entomological and epidemiological surveillance of the chikungunya and dengue infection is established in the departments where the mosquito vector of these two infections is implanted. As part of this monitoring, two indigenous cases of chikungunya infection were confirmed on 24 and 25 September 2010. Additional epidemiological investigations identified the index case (a case of chikungunya imported from India) [36,37].

The risk of initiating a chain of transmission of these two diseases in a country depends, on the one hand, on the risk of introduction of the virus by the arrival of viraemic people and on the other hand the risk of transmission by competent mosquitoes. For Tunisia, the risk of emergence of these two diseases is linked to the risk of return of viremic travelers from endemic areas and the risk of introduction or presence of competent vectors. Regarding vectors, Ae. aegypti was reported in Tunisia $[38,39]$, but was not encountered later. Since then, all the entomological investigations have not revealed the presence of this mosquito in the country. Moreover, Ae. albopictus, the other vector of Dengue and Chikungunya, is not among the 43 species of mosquitos described in Tunisia. Until now it has not been detected in Tunisia, only a specific surveillance will confirm its absence from the Tunisian territory. Many authors confirm the presence of Ae. Albopictus in Algeria [40-42]. In Morocco, studies, reported the establishment of Ae. Albopictus in the country by detection of this mosquito in three breeding sites in the same province of Rabat [43]. This new species will rapidly invade the other countries of northern Africa given the important aerial and maritime links with Southern Europe.

Infected mosquito vectors can also be introduced into the country through the exchange of freight containers, especially through the international trade in used tires. Furthermore, the competence of the mosquitoes of Tunisia with respect to these two arboviruses is unknown. In view of the emergence of indigenous cases of Dengue and Chikungunya in some countries of the Mediterranean basin, the establishment of an alert system based on active epidemiological and entomological surveillance is necessary.

Some species of the genus Aedes are responsible for the transmission of the Zika virus (Zika name of the forest in Uganda where the virus was isolated for the first time in 1947). In Tunisia, the principal vector species probably do not exist (not confirmed). On the other hand, they are present in the Maghreb [44], in Sicily and in southern Europe (Ae. Albopictus). In Tunisia, we have two main 
species Ae. detritus and Ae. caspius. They multiply in the sebkhas after the rains, bit the day but until now, their role in the transmission of the virus Zika has not been demonstrated.

A national surveillance network is essential to monitor and describe the disease and viral circulation over time. In this context, since 2007, Tunisia has been endowed with a national animal welfare monitoring center dedicated to the vigilance and surveillance of animal diseases and the setting up of a specific network for West Nile fever is one of its Priorities and is part of its work in 2009.

\section{Conclusion}

There is a need to update available data on the endemic mosquitoes species present in Tunisia and their geographical distribution. In this context, the actualization and the amelioration of the identification keys of mosquitoes in Tunisia based on morphological criteria and/or molecular biology for species that are closely related are an urgent task. It should be noted that the influence of mosquitoes on human and animals health exceeds the importance that entomologists attribute to them because of their abundance and diversity.

\section{References}

1. Wilkerson RC, Linton YM, Fonseca DM, Schultz TR, Price DC, et al (2015) Making mosquito taxonomy useful: a stable classification of tribe Aedini that balances utility with current knowledge of evolutionary relationships, Plos One 10: 0133602.

2. Freitas LA, Russo CAM, Voloch CM, Mutaquiha OCF, Marques LP, et al. (2015) Diversification of the genus Anopheles and a Neotropical clade from the late Cretaceous, PLoS One 10: 0134462

3. Farid MAŔ (1998) Evaluation of WHOřs antimalaria programme during the past 50 years and prospects for the future. Eastern Mediterranean Health Journal 4: 111-124.

4. Chadli A, Kennoun Mf, Kooli J (1986) Malaria eradication campaigns in Tunisia: history and current state, Archs Inst Pasteur Tunis 63: 35-50.

5. Chahed MK, Bouratbine A, Krida G, Hamida A (2001) Tunisia's receptivity to malaria after its eradication: analysis of the situation for adequacy of surveillance. Bull Soc Pathol Exot 94: 271-276.

6. Pull JH (1979) Simple methodology to estimate the malarial potential of a zone. Technical paper of the Division of Malaria at the World Health Organization.

7. Krida G, Bouattour A, Rhaim A, Kebir A, Jlidi R, et al. (1998) Preliminary investigation of the susceptibility to chlorpyrifos of four anopheles larval samples from Tunisia, Arch Inst Pasteur 4: 199-203.

8. National Institute of Meterology (1999) Climate Atlas of Tunisia.

9. https://www.nis.gov.kh/index.php/en/

10. Bouattour A, Rhaiem A, BachHamba D (1990) Study of the vectorial capacity of Anopheles labranchiae in the Nefza region. Report of the research program of the Pasteur Institute of Tunis, French Cooperation and the National Agency of Environmental Protection. pp: 54-60.

11. Boucheté B, Kennou MF, Chauvet G (1991) Ethology and vectorial capacity of Anopheles from Tunisia in the region of Sidi Bouzid, Geneva.

12. Tabbabi A, Boussès P, Rhim A, Brengues C, Daaboub J, et al. (2015) Larval habitat characterization and species composition of Anopheles mosquitoes in Tunisia, with particular attention to Anopheles maculipennis complex. Am J Trop Med Hyg 92: 653-659.

13. Zahar AR (1974) Review of the ecology of malaria vectors in the Eastern Mediterranean Region. Bull Org Mond Health 50: 427-440.

14. Krida G, Rhim A, Daaboub J, Failloux AB, Bouattour A, et al. (2015) New evidence for the potential role of Culex pipiens mosquitoes in the transmission cycle of West Nile virus in Tunisia. Med Vet Entomol 29: 124-128.
15. Rioux JA, Juminer B, Kchouk M, Croset H (1965) Presence of the autogenous character in Culex piplens pipiens L. in an epic biotope of the island of Djerba. Arch Inst Pasteur Tunis 42: 1-8.

16. Dancesco P, Chadli A, Kchouk M, Horac M (1975) About an autogenic winter seasonal biotope. Bull Soc Pathol Exot 68: 503-507.

17. Roubaud E (1939) Autogenous power in the North African biotype of the common mosquito Culex pipiens. Bull Soc Pathol Exot 36: 172-175.

18. Roubaud E (1993) Synthetic test on the life of the common mosquito Culex pipiens (L.). Nat Sc Nat Bot Zool 16: 5-168.

19. Vermeil C (1954) New contribution to the study of Culex pipiens complex in Tunisia. Bull Soc Pathol Exot 47: 841-843.

20. Krida G, Rhaim A, Bouattour A (1997) Effect of water quality on the expression of the biotic potential of the Culex pipiens mosquito L. in the Ben Arous region (south of Tunis). Bull Soc Entomol France 102: 4-8.

21. Bouattour A, Rhaiem A, Ghrammam M, Younsi H (1998) Entomological survey report following the appearance of West Nile cases. Pasteur Institute of Tunis, Laboratory of Medical Entomology. pp: 5-18.

22. Constantinescu P, Negulici E (1967) The experimental transmission of Plasmodium malariae to Anopheles labranchiae atroparvus. Transactions of the Royal Society of Tropical Medicine and Hygiene 61: 182-188.

23. Ramsdale CD, Coluzzi M (1987) Biology of the plasmodia. Report of a WHO Scientific Group. World Health Organization, Geneva. pp: 15.

24. Reiter P (2000) From Shakespeare to Defoe: Malaria in England in the Little Ice Age. Emerg Infect Dis 6: 1-11.

25. Trape JF (1999) Climate change and infectious diseases: the case of malaria and tick-borne borreliosis. Méd Mal Infect 29: 296-300.

26. Hammadi D, Boubidi SC, Chaib SE, Saber A, Khechache Y, et al. (2009) Malaria in the Algerian Sahara. Bulletin of the Society of Exotic Pathology 102: 185-192.

27. Triki H, Murri S, Guenno B, Bahri O, Hili K, et al. (2001) West Nile viral meningoencephalitis in Tunisia, Médecine Tropicale 61: 487-490.

28. Hachfi W, Bougmiza I, Bellazreg F, Bahri O, Kaabia N, et al. (2010) The second epidemic of West Nile virus meningoencephalitis in Tunisia. Med Mal Infect 40: 456-461.

29. Riabi S, Gaaloul I, Mastouri M, Hassine M, Aouni M, et al. (2014) An outbreak of West Nile Virus infection in the region of Monastir, Tunisia. Pathogens and global health 108: 148-157.

30. Bouatef S, Hogga N, Ben Dhifallah I, Triki H, Bouafif N, et al. (2012) Monitoring and current situation of meningitis and meningoencephalitis to West Nile virus in Tunisia. Tun Rev Infect 6: 181-182.

31. Bahri O, Dhifallah I, Bouafif N, Hekih H, Gargouri J, et al. (2011) Sero epidemiological study of West Nile virus circulation in humans in Tunisia. Bull Soc Pathol Exot 104: 272-276.

32. Ben Hassine T, De Massis F, Calistri P, Savini G, Bel Hadj Mohamed B, et al. (2014) First detection of co-circulation of West Nile and Usutu viruses in equids in the south-west of Tunisia. Transbound Emerg Dis 61: 385-389.

33. Hammouda A, Lecollinet S, Hamza F, Nasri I, Neb A, et al. (2015) Exposure of resident sparrows to West Nile virus evidenced in South Tunisia. Epidemiol Infect 143: 3546-3549.

34. Bargaoui R, Lecollinet S, Lancelot R (2015) Mapping the serological prevalence rate of West Nile fever in equids, Tunisia. Transbound Emerg Dis 62: $55-66$.

35. Krida G, Diancourt L, Bouattour A, Rhim A, Chermiti B, et al. (2001) Estimation of the risk of introduction of the Rift Valley fever virus in Tunisia by the Culex pipiens mosquito. Bulletin of the Society of Exotic Pathology 104: 250-259.

36. Circulaire N (2009) Relating to the implementation of the antidissemination plan for chikungunya and dengue in mainland France. Ministry of Health and Sports, France.

37. Dwayne R (2010) Guide for the implementation of the anti-dissemination plan for chikungunya and dengue in mainland France. Ministry of Health and Sports, France.

38. Brunhes J, Hassaine K, Rhaim A, Hervy GP (2000) The Culicides of Mediterranean Africa: species present and distribution 
Citation: Tabbabi A, Rhim A, Daaboub J (2017) Mosquitoes (Diptera: Culicidae) in Tunisia, with Particular Attention to Proven and Potential Vectors: A Review. J Trop Dis 5: 249. doi:10.4172/2329-891X.1000249

Page 8 of 8

(Diptera:Nematocera). Bulletin of the Entomological Society of France 105: 195-204.

39. Brunhnes J, Rhaim A, Geoffroy B, Angel G, Hervy JP, et al. (1999) Mosquitoes of Mediterranean Africa: Software for identification and teaching.

40. Izri A, Bitam I, Charrel RN (2011) First entomological documentation of Aedes (Stegomyia) albopictus (Skuse, 1894) in Algeria. Clinical Microbiology and Infection 17: 1116-1118.

41. Lafri I, Bitam I, Beneldjouzi A, Benmahdi MH (2014) An inventory of mosquitoes (Diptera: Culicidae) in Algeria. Bull Zoo Soc Fr 139: 255-261.
42. Benallal KE, Allal IA, Benhamouda K, Schaffner F, Harrat Z, et al. (2016) First report of Aedes (Stegomyia) albopictus (Diptera: Culicidae) in Oran, West of Algeria. Acta Tropica 164: 411-413.

43. Bennouna A, Balenghien $\mathrm{T}$, Rhaffouli $\mathrm{H}$, Schaffner $\mathrm{F}$, Grros $\mathrm{C}$, et al (2017) First record of Stegomyia albopicta in Morocco: a major threat to public health in North Africa? Med Vet Entomol 31: 102-106.

44. Tabbabi A, Bekhti K (2017) Recent expansion of Aedes albopictus and factors influencing its beginning invasion in North Africa: A review. J Middle East and North Africa Sciences 3: 6-8. 